\title{
RECENT DEVELOPMENTS IN TRADE BETWEEN THE U.S. AND THE P.R.C.: A LEGAL AND ECONOMIC PERSPECTIVE
}

\author{
David L. Denny* and Daniel D. Stein $\dagger$
}

\begin{abstract}
INTRODUCTION
The recent improvement in political relations between the United States and the People's Republic of China has been accompanied by a considerable growth in trade between the two countries. Since the lifting of the U.S. embargo in 1971, trade has grown so rapidly that the United States has become the P.R.C.'s second largest trading partner. ${ }^{1}$ While the longterm future of U.S.-Chinese trade is necessarily uncertain, the rapid increase in trade that has already occurred has created new opportunities for the American businessman and new challenges for the American attorney. This paper explores those opportunities and challenges by discussing the U.S. regulatory framework for trade with the P.R.C. and the expanding commercial relationship between the countries.
\end{abstract}

\section{The U.S. Regulatory Framework for Trade WITH THE P.R.C.}

The U.S. regulatory framework governing trade with the P.R.C. has changed significantly in the past several years. A total embargo, instituted at the time of the Korean conflict and enforced by the Foreign Assets Control Regulations, ${ }^{2}$ was ended by President Nixon in $1971 .^{3}$ Current

\footnotetext{
*Economist, People's Republic of China Division, Bureau of East-West Trade, U.S. Department of Commerce.

†Trade Development Assistance Officer, Bureau of East-West Trade, U.S. Department of Commerce.

The views expressed herein are those of the authors and do not necessarily reflect those of any government agency.

I This rapid increase in trade has occurred despite the absence of full diplomatic relations between the two governments. What effect, if any, full diplomatic recognition would have on U.S.-P.R.C. trade is a subject beyond the scope of this paper.

231 C.F.R. \$\$ 500.101-500.809 (1973). The Foreign Assets Control Regulations were promulgated on the basis of the Korean Emergency declared by President Truman on December 16, 1950, Proclamation No. 2914, 3 C.F.R. 171 (Supp. 1950), under authority of the Trading With the Enemy Act of 1917, 50 U.S.C. App. $\$ \S 1-44$ (1970). For analyses of the embargo, see Garson, The American Trade Embargo Against China, in China Trade Prospects and U.S. PouICY 1 (A. Eckstein ed. 1971); Lee \& McCobb, United States Trade Embargo on China, 1949-1970: Legal Status and Future Prospects, 4 N.Y.U.J. INT'L L. \& Pol. 1 (1971).

3. This was accomplished through a series of changes in the Foreign Assets Control Regulations, the Export Control Regulations, and various other incidental regulations. Many of these changes are discussed in the body of this paper. For a detailed analysis of all these developments, see Note, Recent Changes in United States Trade Regulations Affecting the People's Republic of China: $A$ Market Decontrolled, 13 VA. J. INT'L L. 78, 86-89 (1972).
} 
U.S. Government policy is to encourage trade with the P.R.C. in nonstrategic commodities. The present U.S. legal framework for international trade consists of controls on both exports and imports as well as restrictions on financing and transportation.

\section{A. Export Controls}

\section{The Export Administration Act}

The Export Administration Act of $1969,{ }^{4}$ now the major mechanism for controlling U.S. exports, provides that such controls may be imposed to the extent necessary: (1) to protect the domestic economy from shortages and from the inflationary impact of abnormal foreign demand, (2) to further U.S. foreign policy and fulfill U.S. international responsibilities, and (3) to protect the national security. ${ }^{5}$ To implement these controls, an export licensing system has been established within the U.S. Department of Commerce under the jurisdiction of the Office of Export Administration (formerly the Office of Export Control), Bureau of East-West Trade. ${ }^{6}$

Under this licensing system, most export trade can be conducted under a "general license," without issuance of any formal documents. A particular validated license, which is a document issued to the exporter by the Department of Commerce, is only required for the export of certain commodities and technical data to specific destinations. For purposes of export control, all foreign destinations are presently divided into seven country groups. A Commodity Control List $^{7}$ enumerates each commodity subject to export control and identifies by country group the destinations for which a validated export license is required. Until February, 1972, the P.R.C. was classified in country group "Z $Z$ " (along with Cuba, North Korea, and North Vietnam), exports to which are stringently controlled. ${ }^{8}$ On February 14, 1972, the P.R.C. was transferred to country group "Y," which includes

\footnotetext{
450 U.S.C. App. $\S \S 2401-2413$ (1970), as amended by the Equal Export Opportunity Act, Pub. L. No. 92-412, 86 Stat. 644 (Aug. 29, 1972).

s It should be noted that, while most Commerce Department export controls have been predicated on the third purpose-protection of the national security-the other two have occasionally been invoked. One of the few examples of the use of the foreign policy rationale is the continuing quasi-embargo on trade with Southern Rhodesia in conformity with United Nations Security Council Resolutions of 1965, 1966, and 1968. The short supply rationale has also been utilized sparingly in the past. During the summer of 1973, however, it was invoked as the basis for new reporting requirements for, and/or controls on, the export of soybeans, other grains and related agricultural products, ferrous scrap, and cotton. While for the most part these controls have been of a temporary nature, their re-imposition and continuation for extended periods of time could have a profound impact on U.S.-P.R.C. trade.

${ }^{6}$ Overlapping provisions of the Foreign Assets Control Regulations, 31 C.F.R. §§ 500.101-500.809 (1973), issued under the authority of the Trading With the Enemy Act of 1917, 50 U.S.C. App. $\$ \$ 1-44$ (1970), impose a Treasury Department license requirement on U.S. exports to the P.R.C. However, a Treasury license is automatically granted for any export which has already been licensed under the Export Administration Act, 31 C.F.R. $\S$ 500.533 (1973).

'Published in U.S. Dep't of Commerce, Export Administration Regulations, and incorporated by reference in 15 C.F.R. $\$ 399.1$ (1974).

${ }^{8}$ Id., 15 C.F.R. $\$ \S 379.1-379.9$ (1974).
} 
the Soviet Union and most Eastern European countries, exports to which are treated more liberally. ${ }^{9}$

\section{2. $C O C O M$}

In 1949, the U.S. helped organize the International Coordinating Committee on Strategic Trade with Communist Countries (COCOM), a voluntary, multilateral organization whose purpose is to enforce controls on the export of strategic items to the communist world. The member countries ${ }^{10}$ meet periodically to review and revise a mutually agreed upon embargo list of commodities and technology. The COCOM list of prohibited exports is less extensive than the list of commodities unilaterally restricted under the Export Administration Act. ${ }^{11}$ Over the past several years, however, the list of items unilaterally controlled by the U.S. has decreased considerably. ${ }^{12}$

\section{Other Export Controls}

The export of certain commodities and technical data is controlled by special legislation and regulations. ${ }^{13}$ Under the authority of the Mutual Security Act of $1954,{ }^{14}$ the export of arms, ammunition, and implements of war is governed by regulations administered by the Office of Munitions Control in the Department of State. The export of gold is under the jurisdiction of the Office of Domestic Gold and Silver Operations in the Department of the Treasury, pursuant to the Gold Reserve Act of $1934^{15}$ and the Trading With the Enemy Act of $1917 .^{16}$ Regulations administered by the Department of Justice under the Controlled Substances Import and Export $\mathrm{Act}^{17}$ govern the export of certain narcotics and dangerous drugs, while the export of nuclear source materials, facilities, and technology must be licensed by the Atomic Energy Commission pursuant to the Atomic Energy Act of $1954 .{ }^{18}$ The Maritime Administration, by authority of the Shipping Act of 1916, governs the export of vessels other than vessels of war, ${ }^{10}$ and the export of natural gas and electric energy is controlled by the Federal Power Commission pursuant to the Natural Gas Act of $1938^{20}$ and the

\footnotetext{
${ }^{9} 8$ WeEkry Compilation of Presidential Documents 438 (1972); 37 Fed. Reg. 3511 , 3520 (1972).

10 The fifteen member nations are the United States, Belgium, Canada, Denmark, France, the Federal Republic of Germany, Italy, Japan, Luxemburg, the Netherlands, Norway, Portugal, the United Kingdom, Greece, and Turkey. list.

11 Under COCOM rules any member nation is free to adopt its own more inclusive embargo

12 For example, as the result of a re-evaluation conducted between October 1972 and May 1973 , the number of restricted commodity categories was reduced from 550 to 73 . See U.S. Dep't of Commerce, Bureau of East-West Trade, Quarterly Report on Export AdMINISTRATION, FOURTH QUARTER 1973, at 23 (1974).

${ }^{13}$ See I5 C.F.R. $\$ 370.10(1974)$.

1422 U.S.C. \$ 1934 (1970).

1531 U.S.C. $\$ \S 440-45$ (1970).

${ }^{16} 50$ U.S.C. App. $\$ 5$ (b) (1970), also codified as 12 U.S.C. \$ 95(a) (1970).

1721 U.S.C. $\$ \S 951-66$ (1970).

1842 U.S.C. $\$ \$ 2011-2282$ (1970).

1946 U.S.C. $\$ \$ 808,835(1970)$.

2015 U.S.C. $\$ 717 \mathrm{~b}(1970)$.
} 
Federal Power Act. ${ }^{21}$ Regulations administered by the Department of Agriculture govern the export of tobacco seeds and plants, ${ }^{22}$ as well as certain fruits. ${ }^{23}$ Finally, the export of migratory birds, along with endangered native fish and wildlife, is subject to regulations of the Department of the Interior, issued in accordance with the Endangered Species Act of 1973. ${ }^{24}$

\section{B. Import Restrictions}

During the period of total embargo, commercial imports from the P.R.C. were barred by the Foreign Assets Control Regulations. When the embargo was lifted in 1971, those regulations were amended so that imports from the P.R.C. are today subject to the same controls as imports from the European communist countries. ${ }^{25}$

\section{Most-Favored-Nation Treatment}

The most important restriction on U.S. imports from the communist world is the absence of most-favored-nation (MFN) tariff treatment. Under our two-column tariff schedule, ${ }^{26}$ many imports from countries not enjoying MFN status are subject to higher duties than comparable imports from countries whose products enjoy MFN treatment. Naturally this puts the products of the non-MFN country at a competitive disadvantage on the U.S. market. The actual difference between the import duty varies from product to product, but is generally smaller for raw materials than for finished goods.

Under present law, MFN status may not be extended to communist countries except for Yugoslavia and Poland. ${ }^{27}$ Early in 1973, President Nixon submitted to Congress trade legislation which would have allowed the President to grant MFN status to communist countries, including the P.R.G. However, the version of the bill passed by the House as the Trade Reform Act of $1973^{28}$ makes the products of a non-market economy country which places restrictions on the free emigration of its citizens ineligible for MFN treatment. ${ }^{29}$ This limitation was a response to Soviet emigration policy, particularly the treatment of Jews wishing to emigrate to Israel, but it would also apply to the P.R.C., which does not allow free emigration as defined in the bill. As of this writing, the Trade Reform Bill is awaiting action in the Senate.

\section{Market Disruption Legislation}

Under the Antidumping Act of $1921,{ }^{30}$ the Secretary of the Treasury

\footnotetext{
${ }^{21} 16$ U.S.C. $\$ 824 \mathrm{a}(\mathrm{e})(1970)$.

227 U.S.C. $\$ 516(1970)$.

237 U.S.C. $\$ \S 581-99$ (1970).

${ }^{24}$ Pub. L. No. 93-205, 87 Stat. 884 (Dec. 28, 1973).

${ }^{26} 19$ U.S.C. \$ 1202 (1970).

2719 U.S.C. $\$ 1861$ (1970).

${ }^{28}$ H.R. 10710, 93d Cong., 1st Sess. (1973).

${ }^{29}$ Id. $\S 402$ (a).

30 19 U.S.C. $\S \$ 160-71$ (1970).
}

2531 C.F.R. $\$ 500.547$ (1973). Noncommercial imports of P.R.C. goods had been authorized since 1969, see 34 Fed. Reg. 20,189 (1969), which was codified as 31 C.F.R. $\$ 500.544$, but which was revoked as unnecessary in 1971 because of the addition of section 500.547 to the Foreign Assets Control Regulations, 36 Fed. Reg. 11,441 (1971). 
is required to levy a special dumping duty against foreign goods sold in the U.S. at less than their fair value when there is a finding by the Tariff Commission that such sale causes injury to an American industry. Although the potential problem of market disruption by the dumping of goods from communist countries has been suggested by several writers, ${ }^{31}$ there have been to date no major dumping problems with P.R.C. exports to the U.S. Potential market disruption from imports can also be dealt with by the countervailing ${ }^{32}$ and equalization duties ${ }^{33}$ under the Tariff Act of 1930 and tariff adjustments ${ }^{34}$ under the Trade Expansion Act of 1962, but these provisions have rarely, if ever, been invoked against imports from communist countries.

Specifically applicable to U.S. trade with China is special interest legislation which prohibits the importation of seven kinds of furskins from the P.R.C. and the Soviet Union. ${ }^{35}$ Also implicitly barred is the importation of the skins of animals on the Department of the Interior's "endangered species" list. ${ }^{36}$ Finally, imports of textile products are subject to the recently negotiated Arrangement Regarding International Trade in Textiles. ${ }^{37}$ The P.R.C. is not a party to this agreement, but under its terms, textile imports from the P.R.C. could not be treated more favorably than those from participating countries.

\section{Financing Restrictions}

\section{Export-Import Bank}

The Export-Import Bank (Eximbank) serves an important role in the medium and long-term financing of American exports by offering low interest loans and guarantees to encourage the participation of private banks. Under current legislation, Eximbank itself cannot participate in transactions with a communist country without a presidential determination that such participation is in the U.S. national interest. ${ }^{38}$ Until recently the question of Eximbank financing for sales to the P.R.C. has been academic because the P.R.G. followed a general policy of purchasing from abroad only for cash or through short-term credits. In the last several years, how-

${ }^{31}$ See Hoya, The Changing U.S. Regulation of East-West Trade, 12 Colum. J. Transnat'L L. 1, 19-20 (1973). See also S. Pisar, Coexistence and Commerce: Guidelines for Transactions Between East and West 232-35 (1970); Anthony, The American Response to Dumping From Capitalist and Socialist Economies-Substantive Premises and Restructured Procedures After the 1967 GATT Code, 54 CoRnell L.Q. 159 (1969); Berman, The Legal Framework of Trade Between Planned and Market Economies: The Soviet-American Example, 24 LAw \& ConTEMP. Prob. 482 (1959); Feller, The Antidumping Act and the Future of East-West Trade, 66 Mich. L. REv. 115 (1967).

3219 U.S.C. \& 1303 (1970).

${ }^{33} 19$ U.S.C. $\$ 1336$ (1970).

3419 U.S.C. $\$ \$ 1901,1981$ (1970).

${ }^{35}$ Revised Tariff Schedules, Schedule 1, pt. 5, subpt. B, headnote 4, 19 U.S.C. $\$ 1202$ (1970).

${ }^{36}$ Endangered Species Act of 1973, § 9, Pub. L. No. 93-205, 87 Stat. 884 (1974).

${ }^{37}$ GATT TEX. NG/1, done at Geneva, Dec. 20, 1973, entered into force for the United States, Jan. 1, 1974 (except for art. 2, II 2, 3, \& 4, which entered into force Apr. 1, 1974). See 70 DEP'T State Bull. 155 (1974).

${ }^{38}$ Such presidential determinations of national interest have been made with respect to Yugoslavia (May, 1968), Romania (Nov., 1971), the U.S.S.R. (Oct., 1972), and Poland (Nov., 1972). 12 U.S.C. § 635(b) (2) (1970). 
ever, there has been a growing tendency on the part of the P.R.C. to finance purchases on a medium-term basis. Whether the trend will continue is unclear at this point, but if it does, the question of Eximbank credits and guarantees may arise. ${ }^{39}$ Again, the Trade Reform Bill passed by the House of Representatives creates potential problems as it precludes participation in any U.S. Government credit program by countries restricting free emigration. ${ }^{40}$

\section{The Johnson Act}

The Johnson Debt Default Act of 1934 prohibits individuals and firms within the United States from engaging in certain financial transactions with a foreign government or its securities when that government is in default of its obligations to the United States. ${ }^{41}$ Whether the Johnson Act applies to the P.R.C. turns on the defaulted obligations of the Republic of China which the government of the P.R.C. refuses to recognize as its own. Under general principles of international law, a successor government is bound by the obligations of its predecessor, ${ }^{42}$ but complications arise in this case because the "predecessor" government continues to exist on Taiwan, claiming to be the only legitimate government of China.

In any event, the actual scope of the Johnson Act has been severely limited by Opinions of the Attorney General. For example, the Act has been held not to apply to export sales on a deferred payment basis, ${ }^{43}$ lines of bank credit, barter arrangements, and deferrals of payment pending development of earnings. ${ }^{44}$ The Attorney General has also ruled that the Act does not apply to the operations of foreign branches of American banks when the branches are incorporated in the foreign country. ${ }^{45}$ Whether this limitation extends to unincorporated foreign branches and whether the Act applies to a myriad of other possible financing arrangements is still open to question. ${ }^{46}$

\section{Public Law 480}

A final constraint upon the financing of trade with the P.R.C., though one of limited practical import, relates to Public Law 480 agricultural pro-

\footnotetext{
${ }^{30}$ An unresolved issue is liability for four defaulted loans made by Eximbank to the Republic of China prior to 1947. These loans may be attributed to the government of the P.R.C. See note 42 infra and accompanying text.

${ }^{40}$ H.R. 10710, 93d Cong., lst Sess. § 402 (1973).

4118 U.S.C. \$955 (1970). The original Act specifically exempted U.S. Government corporations, see Act of Apr. 13, 1945, ch. 112, $\S 1-2,48$ Stat. 574. Current legislation provides exemptions also for any foreign government that is a member of both the International Monetary Fund and the International Bank for Reconstruction and Development, 18 U.S.C. $\$ 955$ (1970), and for any transaction involving Eximbank participation, 12 U.S.C. $\$ 635 \mathrm{~h}$ (1970).

42 See, e.g., 37 OP. ATT'y GEN. 505, 513-14 (1934).

4342 Op. ATt'y Gen., Op. No. 15, at 6 (1963).

4442 Op. AtT'y Gen., Op. No. 27, at 5 (1967).

4539 Op. ATT'y Gen. 398, 401-02 (1939).

${ }^{46}$ See Starr, A New Legal Framework for Trade Between the United States and the Soviet Union: The 1972 US-USSR Trade Agreement, 67 AM. J. INT'L L. 63, 82 (1973).
} 
grams. ${ }^{47}$ These programs generally provide for long-term government financing of sales of agricultural commodities to "friendly" countries, excluding any country "dominated or controlled by a foreign government or organization controlling a world Communist movement" and any country whose ships or aircraft engage in trade with Cuba or North Vietnam.48

\section{Miscellaneous Transportation Regulations}

Pursuant to the Defense Production Act of $1950^{49}$ the Departments of Commerce and Transportation have issued transportation orders prohibiting U.S. flag sea or air carriers from transporting certain controlled commodities to most communist countries (including the P.R.C.) without a validated export license. ${ }^{50}$ This prohibition applies to goods shipped from foreign ports as well as to shipments from the U.S. ${ }^{51}$ There are also several transportation regulations of general applicability that might affect U.S.P.R.C. trade, such as the bunkering provisions-pertaining to ships and planes calling on North Vietnam or North Korea-of the Export Administration Regulations ${ }^{52}$ and other legislatively-mandated cargo preference rules. ${ }^{53}$

\section{E. Settlement of Claims}

The China Claims Act of 1966 authorizes the Foreign Claims Settlement Commission to certify private claims by U.S. nationals against the P.R.C. which have resulted from wrongful death or disabilities, nationalizations, or other takings of property since $1949 .{ }^{54}$ Simultaneously, assets owned or controlled by the P.R.C. or its nationals, but located in the U.S., remain blocked under provisions of the Foreign Assets Control Regulations..$^{55}$ Both the outstanding claims against the P.R.C. and the possibility that P.R.C. property in the U.S. may be attached are impediments to normalized trade between the two countries. Due to the fear of attachment, P.R.C. vessels are unlikely to venture into U.S. ports, and the P.R.C. has been wary of taking legal delivery of goods within the territory of the U.S. ${ }^{56}$ Resolution of the claims and blocked assets issues would thus be an important step in facilitating U.S.-Chinese trade.

${ }^{47}$ Agricultural Trade Development and Assistance Act of 1954, 7 U.S.C. $\$ \S 1691,1701$ 10 (1970).

${ }_{48}$ Id. $\& 1703(\mathrm{~d})$.

4950 U.S.C. App. $\S \S 2061-2168$ (1970).

50 32A C.F.R. ch. VII (1973).

51 Dep'ts of Commerce \& Transportation Order No. T-1, Int. 1, 32A C.F.R. ch. VII (1973). Dep'ts of Commerce \& Transportation Order No. T-2, id., flatly prohibits U.S. flagships or aircraft from calling at ports in North Korea and North Vietnam and from transporting or loading any cargo ultimately destined for North Korea or North Vietnam. The P.R.C. was covered by these same prohibitions until they were amended in 1971. See 36 Fed. Reg. 8672 (1971).

5215 C.F.R. $\$ 3371.9$ (b) (1) \& (2), 371.10(b) (1974).

5346 U.S.C. $\$ 1241$ (b) (1) (1970).

5422 U.S.C. $\$ 1643(1970)$.

5531 C.F.R. $\$ \S 500.101-500.809$ (1973).

${ }^{56}$ As has been pointed out, suits based on claims against the P.R.C. would raise complex legal questions. See Starr, Developing Trade With China, 13 VA. J. INT'L. L. 13, 29 (1972). 


\section{The Expanding Commercial Relationship}

In 1973, the second full year of direct commercial relationships, the U.S. became China's second largest trading partner. While the U.S. is certain to remain one of China's largest trading partners in 1974, there are a number of reasons for being cautious about the extent of U.S.-China trade in the future. Part I of this article has shown that several important steps remain to be taken before American and Chinese enterprises can compete on an equal basis in each other's marketplace. In addition, the businessmen, business practices, and products of both countries need greater exposure before the long-term future of trade between the two countries will be clarified. At least with regard to farm products, trade between the U.S. and the P.R.C. can be expected to fluctuate substantially since China's foreign trade is sensitive to variations in the domestic agricultural harvest. Finally, long-term forecasts are difficult because trade in the P.R.C. is centrally planned and thus can be changed rapidly unlike that of the U.S.

\section{A. Commodity Trade ${ }^{57}$}

\section{Magnitude}

Trade between the U.S. and the P.R.C. grew from $\$ 5$ million in 1971 (including indirect imports from China via third countries) to $\$ 95.9$ million in 1972 (\$63.5 million U.S. exports, $\$ 32.4$ million U.S. imports) and to about $\$ 800$ million in $1973 .{ }^{58}$ In the first quarter of 1974 , total trade already exceeded $\$ 380$ million and is expected to exceed $\$ 1$ billion by the end of the year.

Because of the larger size of the American economy and of its foreign trade sector, U.S.-Chinese trade will have a smaller impact on the U.S. economy than on that of the P.R.C. In 1973, trade between the United States and the P.R.C. accounted for 0.6 per cent, 1.0 per cent, and 0.1 per cent respectively of U.S. foreign trade, U.S. exports, and U.S. imports. While the China trade has had a significant impact on particular American products (such as agricultural exports) and companies, its major importance for the U.S. lies in its potential: at its current rate of growth, China's total foreign trade would increase eight times in the next two decades. ${ }^{59}$ Such an expansion would

\footnotetext{
${ }^{57}$ Unless otherwise specified, the source of all trade data found in this section is U.S. Bureau of the Census, Dep't of Commerce, Highlights of Exports and Imports (Foreign Trade Div. Rep. No. 990, 1974). This publication is issued monthly by the Foreign Trade Division; the issues utilized for the purposes of the following analysis were Jan., Feb., Mar., and Apr., 1974. Also utilized for contrasting illustrations were the issues for Jan., 1972 and Jan., 1973.

ss Official 1973 data for trade with China $(\$ 67$ million worth of U.S. imports and $\$ 690$ million worth of exports) do not reflect the transshipment through Canada of about $\$ 50$ million worth of agricultural products.

${ }^{59}$ Eckstein \& Reynolds, Sino-American Trade Prospects and Policy, 64 AM. Econ. Rev., May 1974, at 294,296 . The authors argue that "a 10 per cent average annual foreign trade growth rate seems more plausible between 1972 and 1980." Under normalized conditions they project a total trade turnover of $\$ 2$ billion and U.S. imports of from $\$ 300$ to $\$ 400$ million (constant 1973 prices). Id. at 298.
} 
present substantial opportunities indeed for the U.S. economy which tends to export many of the products China imports.

On the other hand, U.S.-China trade accounted for nearly 10 per cent of China's total trade and 16 per cent of its imports in 1973. Trade with the United States provides China with a source of supply, especially for agricultural products, where there are very few large and reliable alternatives. Much has been made of the fact that the U.S. has become China's second largest trading partner; more should be made of the fact that this has given China the opportunity to avoid becoming overly reliant on its other major trading partners.

\section{Trade Imbalance}

A substantial imbalance exists in the commodity trade between the two countries: U.S. exports to China were twelve times U.S. imports in 1973. Since their reorientation of trade away from the Soviet Union and East Europe, Chinese planners have not sought to balance trade bilaterally with each trading partner. Until last year, the P.R.C. ran large trade deficits with Japan and Western Europe, paying for the difference with hard currency earned in Hong Kong and Singapore. If China continues to find the United States an attractive source of agricultural and high technology industrial products, there seems to be nothing in Chinese practice or ideology that requires bilateral trade balances. On the other hand, the Chinese put a great deal of emphasis on the principles of "equality and mutual benefit" which were part of the Shanghai Communique signed at the end of President Nixon's 1972 trip to China. ${ }^{60}$ In that regard, the attainment of nondiscriminatory tariff and credit treatment may be a significant factor in China's future trade decisions.

The importance of discriminatory tariff treatment presents a complex question. Two studies have argued that granting MFN status per se is not likely to significantly increase Chinese exports to the U.S. ${ }^{61}$ This prediction is generally consistent with conclusions regarding East European nonmarket economies in the past, ${ }^{62}$ though one recent analysis suggests the opposite. ${ }^{63}$ Unfortunately, the available studies use static models which are unable to account for the re-evaluation of foreign trade now underway in many non-market economies. When basic changes are possible it makes

${ }^{60} 66$ DeP'T State Bull. 567 (1973).

${ }^{61} \mathrm{~J}$. Jelacic, Impact of Granting Most Favored Nation Treatment to the Countries of Eastern Europe and THE PeOple's Republic of China (U.S. Tariff Comm'n Staff Research Studies, No. 6, 1974); Haas, Impact of MFN on U.S. Imports from the PRC, ScHool oF Advanced Studies Rev. (Winter, 1973).

$62 \mathrm{~T}$. Wolf, The Quantitative Impact on Liberalization of United States Unilateral Restrictions on TRADE with Socialist Countries of EASTERN Europe (U.S. Dep't of State, External Research Study No. XR/RECS-3, Feb. 16, 1972).

63 Elias \& Searing, A Quantitative Assessment of U.S. Constraints in Trade with Eastern Europe and the U.S.S.R., in JoInt Economic Committee Print, Reorientation and Commercial Relations of the Economies of EAstern Europe, 93d Cong., 1st Sess. (1973). The authors conclude: "Compared with our actual imports from the socialist countries, the estimates indicate that 'normalized' U.S. imports from Eastern Europe and the U.S.S.R would have been in excess of four times larger in 1971 than they actually were." The authors suggest that more than half of the difference is due to the higher (non-MFN) tariff rates. 
little sense to assume that a country's foreign trade level or its commodity composition is immutable. While there is debate about the economic importance of MFN treatment, there is, however, no disagreement about the P.R.C.'s obvious desire to end the discriminatory treatment for diplomatic and political reasons.

\section{Concentration of Commodity Trade}

The concentration of U.S.-P.R.C. commodity trade is shown in Table I. The ten leading U.S. exports account for 96.3 per cent of the total while the

TABLE I

U.S. Trade With China

Ten Leading Exports and Imports in 1973

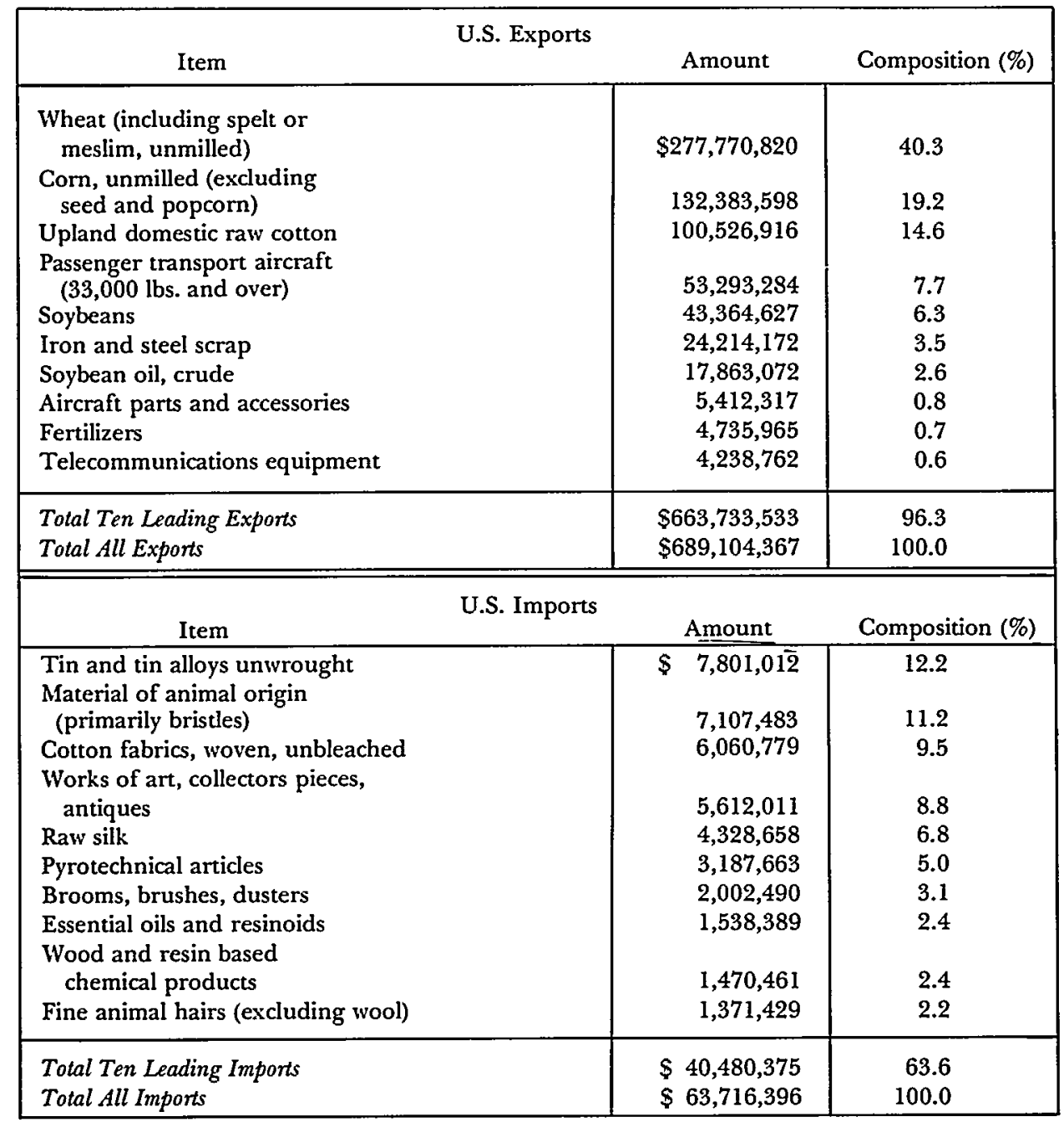

Source: 1 U.S.-China BuS. Rev. No. 2, at 11 (1974). 
ten leading P.R.C. exports account for only 63.6 per cent of their total. The U.S. exported a total of 28 different commodities (using the four-digit standard international trade classification) to China, while the P.R.C. exported 186 different commodities to the U.S.

Perhaps the most important feature of U.S. exports to China is the overwhelming importance of a few agricultural commodities (wheat, corn, soybeans, soybean oil, and cotton). In retrospect, it is clear that detente came at a fortuitous time for China's planners and for American agricultural exporters. China had suffered a bad harvest in 1972 and might have had difficulty in securing even its usual level of grain imports from its normal suppliers in $1973 .{ }^{64}$ By contrast, China's harvest improved considerably last year and three-year grain import contracts have recently been signed with Canada, Australia, and Argentina. Nevertheless, these contracts still leave China about two million tons short of the import levels of the past decade (and much further below import levels of the past two years). Thus, the potential for significant U.S. grain sales may still exist, albeit in a lesser amount than in 1973 or 1974.

Although the future of Chinese imports of American agricultural products is thus uncertain, most observers are more sanguine about the P.R.C. becoming a relatively large and stable purchaser of U.S. cotton. This too rests on analyses of Chinese agriculture that cannot be very certain, but the difficulty of withdrawing land from grain cultivation will likely cause China's textile industry to require considerably more cotton than can be produced domestically. A final uncertainty in the agricultural area has been introduced by proposals to strengthen the short supply aspect of U.S. export control legislation. ${ }^{65}$ In the past year, two substantial American exports to China (iron and steel scrap and soybean oil) have already been subjected to such controls. These commodities together with grain, corn, and soybeans accounted for 84 per cent of all U.S. exports to China.

A second group of important exports to the P.R.C. involves industrial products that generally incorporate advanced technology. Examples include Boeing 707 aircraft, earth satellite stations, fertilizer plants, and petroleum exploration equipment. Such exports may necessitate the approval of both the U.S. Government and COCOM, but it should be noted that the Office of Export Administration denied licenses valuing less than $\$ 3$ million in equipment and technical information for all communist countries in $1973 .{ }^{66}$ Moreover, all but $\$ 10,000$ of the rejected sales were commodities under COCOM security export control. Assuming that China continues to purchase high technology

\footnotetext{
${ }^{64}$ The discussion of Chinese agriculture is based primarily on material included in U.S. Dep't of agriculture, Economic Research Service, The Agricultural Situation in the people's Republic of China and Other Asian Communist Countries: Review of 1973 anOutLOOK FOR 1974 (1974).

${ }_{65}$ See Jones, Calls Grow Louder for Exports Curbs, N.Y. Times, May 20, 1974, at 47, col. 4. Mr. Jones writes that "fears of shortages are spurring demand for still wider export controls. More than two dozen bills before Congress call for quotas, even embargos, on the export of a wide range of raw materials, agricultural products and all energy resources or natural resources."

${ }^{66}$ U.S. Dep'T of COMMERCE, supra note 12, at 70.
} 
products from the West, the U.S. will undoubtedly be among the leading sellers of equipment for mining, construction, petroleum production, aviation, telecommunication, and the electronics industry, though American firms face generally strong competition from Japan and Western Europe.

Unlike its American imports, China's exports to the U.S. are composed of a large number of commodities. One of the reasons for such diversity is the desire on the part of Chinese exporters and American importers to test the acceptance of Chinese products on the American market. The small quantity of supplies made available to American importers and the difficulty of arranging assured future supplies has been a source of concern to large retailers accustomed to dealing in minimum lots several times larger than the Chinese can supply. Among the many reasons for this problem are high tariff differentials (which make selling in the United States extremely costly for all but token quantities of some commodities) and production constraints on many Chinese exports. While the dollar value of Chinese exports has grown phenomenally in recent years, much of the increase is due to rising prices so the real rate of growth is lower than it first appears. Out of available exports, Chinese foreign trade corporations have to satisfy old as well as new customers. When the additional difficulties of acquiring knowledge about American laws and marketing techniques is taken into consideration, it is not surprising that the P.R.C.'s exports to the U.S. have grown only moderately.

Tariff problems and the restrictions on furskins aside, American law treats imports from China on a par with imports from all other countries. This, of course, does not mean that there are no barriers to expansion of imports from the P.R.C. American laws impose stringent conditions on imports of food and drugs, while American packaging and labeling requirements present special problems for the exporter who is new to the market. Finally, both domestic laws and multilateral commitments of the U.S. make certain products, such as textiles, subject to possible future restraints.

One of the most optimistic signs that both sides look forward to a positive and continuing commercial relationship in spite of these difficulties is the effort that has gone into collection and exchange of information needed to overcome the problems of entering a new market. The Chinese have been assisted by tours and information provided by the U.S. Government, as well as by individual businessmen and business groups. In addition, Chinese commercial officials have shown a considerable interest in eliciting a wide range of information about our economy, business, and commercial practices. The results of these efforts are beginning to produce tangible evidence of success. In the most recent Canton Export Commodities Fairs, U.S. businessmen have reported increased willingness to discuss labeling improvements, styling to suit Western tastes, improved packaging, and the like. ${ }^{67}$ No one should expect a massive influx of imports

\footnotetext{
${ }^{67}$ A recent New China News Agency report stated: “China's foreign trade corporations... convassed the opinions and demands of the people of other countries as regards the quality, variety, colours and designs, specifications, packing, and prices of Chinese export commodities." B.B.C., Summary of World Broadcasts (Rep. No. FE/4602/C1/1, May 17, 1974). For
} 
due to changed P.R.C. standards as the problems are complex, but the Chinese are cautiously moving to resolve them. It is also worth remembering that many of the problems discussed above are not unique to the American market. P.R.C. planners have encountered similar problems in their trade with other countries and undoubtedly will encounter more if trade continues to expand.

\section{B. Shipping and Financing}

Until the blocked assets and fixed claims issues are resolved, assets of the P.R.C. in the U.S. are subject to possible attachment in U.S. courts, making transport of commodities in P.R.C. ships impossible. In addition, although American law permits U.S. ships to enter P.R.C. ports, the P.R.C. has not yet allowed such entry. Discussion of airline service between the two countries also awaits resolution of the same issues. These restrictions on commercial transportation have not prevented a dramatic increase in trade between the two countries for several reasons. First, the P.R.C. arranges for a great part of its trade by chartering third country flag ships. In addition, a substantial part of the trade (especially U.S. imports and miscellaneous industrial exports) has been transshipped through Hong Kong and Japan. Both the U.S. and the P.R.C. have regular shipping service with both locations; in fact, at least one company has ships that call at both American and Chinese ports. As of this date, however, trade has been insufficient to justify direct regular shipping between the U.S. and the P.R.C.

The blocked assets and fixed claims issues have also hampered normalization of banking relations between the two countries. Since the possibility of attachment prevents the Bank of China from having accounts in U.S. banks, the P.R.C. has restricted American banks to relatively trivial aspects of direct commercial banking. As in transportation, third country institutions have facilitated the development of trade by providing letters of credit, handling commercial documents, and settling financial transactions through their accounts with the Bank of China. Unlike transportation firms, however, American banks have been able to join foreign banks in consortia which finance both industrial and agricultural exports to the P.R.C. ${ }^{68}$ As indicated above, China has begun to finance large industrial purchases by deferring payments over a period of five years, a method of financing partly underwritten (especially in Japan) by national export promotion banks that make loans at six to seven per cent interest, a practice which the U.S. Eximbank may not employ. While this prohibition has not prevented China from making large purchases in the U.S., where sellers have arranged normal commercial financing, it surely reduces the competitiveness of some U.S. exports.

Despite the ability of the present institutional structure to handle a large amount of trade, normalization of transportation and banking chan-

a report on the successful resolution of two such problems involving American companies, see Buxbaum, Two Cases of Dispute Settlement, 1 U.S.-China Bus. Rev. 13, 14 (1974).

${ }^{68}$ Note Financing Agricultural Exports to China, 1 U.S.-CHINA Bus. REv. 52 (1974). 
nels would benefit both parties. The Chinese are substantially increasing their port and shipping facilities, suggesting that direct shipping and the use of their own fleet may be more important in the future. In addition, they have already signed air agreements with Japan and a number of Western countries (including Canada). It seems likely that the Chinese will, in time, wish to add the U.S. to their growing international airline service. A number of U.S. air lines would welcome the opportunity to obtain a reciprocal route from the Civil Aeronautics Board once an air agreement has been reached between the two governments. The present banking system forces the American and foreign banks to split fees for normal financial charges and places the burden of commercial transactions on small branches of foreign banks. Large domestic banks could bring much greater resources to facilitating letters of credit and documentary exchanges. Direct banking relationships would undoubtedly encourage U.S. banks to develop more expertise about the economy, products, and financial practices of China. The whole process could lead to an increased willingness of banks to make loans to U.S. firms engaged in business with China.

\section{CONCLUSION}

The renewal of relations with China after two decades of isolation has enabled the United States to become a major trading partner of China, and there are good reasons to believe that this trade rests on a solid basis. China has been a consistent importer of agricultural commodities and technological products, areas in which the U.S. producers are very competitive. Similarly, China has raw materials, foodstuffs, and traditional products that have already demonstrated a degree of success on the American market. For the future, the P.R.C. can be expected to begin manufacture of cameras, bicycles, and other light industrial products that are now becoming more expensive in other developing countries.

Despite this generally optimistic picture, we have emphasized that a few important issues cloud the future commercial relations between the two countries. Some of these matters involve the uncertainties of future U.S. legislation, such as short-supply export controls and MFN status, while others involve negotiation between the two countries over questions of mutual interest. Examples of the latter include blocked assets, methods of settling contractual disputes, banking arrangements, and transportation channels. Even when these issues are resolved, the size and character of future U.S.-China trade will be difficult to predict until Chinese trading corporations and U.S. firms gain more experience with each other. President Nixon's "opening to China" created the foundation for a sound economic relationship; the next few years will be filled with the more mundane but equally important tasks of gaining the knowledge and fashioning the institutions that are necessary to put the relationship on a more permanent basis. 